\title{
Stage IIA Testicular Cancer AJCC v8
}

National Cancer Institute

\section{Source}

National Cancer Institute. Stage IIA Testicular Cancer A/CC v8. NCI Thesaurus. Code C140234.

Stage IIA includes: (Any pT/TX, N1, M0, S0); (Any pT/TX, N1, M0, S1). TX: Testicular cancer in which the primary tumor cannot be assessed. N1: T esticular cancer with metastasis with a lymph node mass $2 \mathrm{~cm}$ or smaller in greatest dimension and less than or equal to five nodes positive, none larger than $2 \mathrm{~cm}$ in greatest dimension. M0: Testicular cancer without evidence of distant metastasis. S0: Marker study levels within normal limits. S1: LDH less than $1.5 \times \mathrm{N}$ and $\mathrm{hCG}(\mathrm{mlU} / \mathrm{mL})$ less than 5,000 and AFP (ng/mL) less than 1,000. $\mathrm{N}$ indicates the upper limit of normal for the LDH assay. (AJCC 8th ed.) 